\title{
Aspects of lithium tri- and tetraborate synthesis in the subsolidus region
}

\author{
(C) Svetlana G. Mamontova, Alexander A. Dergin, Alexander I. Nepomnyashchikh, \\ Ekaterina V. Kaneva
}

A.P. Vinogradov Institute of Geochemistry SB RAS, Irkutsk, Russian Federation

\begin{abstract}
The present work is focused at studying the transformation patterns for the crystalline structure of phases formed during the synthesis of polycrystalline lithium tri- and tetraborate. In the field of lithium triborate $\left(\mathrm{LiB}_{3} \mathrm{O}_{5}\right)$ and tetraborate $\left(\mathrm{Li}_{2} \mathrm{~B}_{4} \mathrm{O}_{7}\right)$ of the $\mathrm{Li}_{2} \mathrm{O}-\mathrm{B}_{2} \mathrm{O}_{3}$ system, $\mathrm{LiB}_{3} \mathrm{O}_{5}$ and $\mathrm{Li}_{2} \mathrm{~B}_{4} \mathrm{O}_{7}$ polycrystalline powders were synthesised. In terms of precursors, lithium carbonate $\left(\mathrm{Li}_{2} \mathrm{CO}_{3}\right)$ and boric acid $\left(\mathrm{H}_{3} \mathrm{BO}_{3}\right)$ were selected. Two synthesis methods were tested including precipitation from solution and solid-phase synthesis. As a result, the direct sintering of a mechanically-grinded stoichiometric precursor mixture is shown to be the optimal method for crystallising $\mathrm{LiB}_{3} \mathrm{O}_{5}$ and $\mathrm{Li}_{2} \mathrm{~B}_{4} \mathrm{O}_{7}$. The crystallisation patterns of lithium borates were studied in a temperature range of $500-850^{\circ} \mathrm{C}$ with sampling carried out every $50^{\circ} \mathrm{C}$. Individual phase portraits were established presenting a set of process characteristics depending on the level of substance particle organisation and subsolidus crystallisation from the initial reagent mixture of lithium tri- and tetraborate at the phase, local and structural levels. In a lithium triborate stoichiometric mixture, the maximum conversion of crystalline phases is observed in the region of $500-600^{\circ} \mathrm{C}$, while, for lithium tetraborate, the temperature maximum is in the range of $600-700^{\circ} \mathrm{C}$. The sequence of phase transformations remains almost unchanged and occurs according to the following scheme: starting reagents > intermediate metastable phases $>$ final borates. The local level of phase portraits characterises the interaction of coordination polyhedra forming the crystal lattice of the studied phases. Solid-phase synthesis of crystalline $\mathrm{LiB}_{3} \mathrm{O}_{5}$ from the $\mathrm{Li}_{2} \mathrm{CO}_{3}$ and $\mathrm{H}_{3} \mathrm{BO}_{3}$ takes place as a result of $\left(\mathrm{BO}_{3}\right)^{3-} \rightarrow\left(\mathrm{B}_{3} \mathrm{O}_{7}\right)^{5-}$ transition with the $\left(\mathrm{BO}_{3}\right)^{3-} \rightarrow\left(\mathrm{B}_{4} \mathrm{O}_{9}\right)^{6-}$ scheme realised in obtaining $\mathrm{Li}_{2} \mathrm{~B}_{4} \mathrm{O}_{7}$. At the crystal structure level, such transitions correspond to transformations of the monoclinic lattice of the $\mathrm{Li}_{2} \mathrm{CO}_{3}$ and $\mathrm{H}_{3} \mathrm{BO}_{3}$ primary phases into the $\mathrm{LiB}_{3} \mathrm{O}_{5}$ and $\mathrm{Li}_{2} \mathrm{~B}_{4} \mathrm{O}_{7}$ rhombic and tetragonal structure, respectively. In this case, an intermediate step of this transformation consists in formation of the $\mathrm{LiBO}_{2}$ trigonal chain metaborate and metastable $\mathrm{Li}_{2} \mathrm{~B}_{8} \mathrm{O}_{13}$.
\end{abstract}

Keywords: borate synthesis, lithium triborate, lithium tetraborate, $\mathrm{Li}_{2} \mathrm{O}-\mathrm{B}_{2} \mathrm{O}_{3}$ system, solid-phase synthesis, phase portrait of crystallization

Acknowledgments: The data presented were obtained using the equipment of the Centre for Collective Use "Isotope Geochemical Research", SB RAS. The study was carried out as a part of the State assignment IX.25.3.2 "Crystal and amorphous functional materials with predictable properties" (0350-2019-0002).

Information about the article: Received August 31 2019; accepted for publication February 25, 2020; available online March 31, 2020.

For citation: Mamontova SG, Dergin AA, Nepomnyashchikh AI, Kaneva EV Aspects of lithium tri- and tetraborate synthesis in the subsolidus region. Izvestiya Vuzov. Prikladnaya Khimiya i Biotekhnologiya = Proceedings of Universities. Applied Chemistry and Biotechnology. 2020;10(1):6-13. (In English) https://doi.org/ 10.21285/2227-2925-2020-10-1-6-13

\section{Особенности синтеза три- и тетрабората лития в субсолидусной области}

\author{
С.Г. Мамонтова, А.А. Дергин, А.И. Непомнящих, Е.В. Канева \\ Институт геохимии им. А.П. Виноградова СО РАН, г. Иркутск, Российская Федерация
}

Резюме: Целью работы являлось исследование закономерностей преобразования кристаллической структуры фраз, образующихся в процессе синтеза поликристаллических три- и тетрабората лития. В области существования трибората лития ( $\left.\mathrm{LiB}_{3} \mathrm{O}_{5}\right)$ и тетрабората лития $\left(\mathrm{Li}_{2} \mathrm{~B}_{4} \mathrm{O}_{7}\right) \mathrm{cucmemы}$ 
$\mathrm{Li}_{2} \mathrm{O}-\mathrm{B}_{2} \mathrm{O}_{3}$ синтезированы поликристаллические порошки $\mathrm{LiB}_{3} \mathrm{O}_{5}$ и $\mathrm{Li}_{2} \mathrm{~B}_{4} \mathrm{O}_{7}$. В качестве исходных реактивов выбраны карбонат лития $\left(\mathrm{Li}_{2} \mathrm{CO}_{3}\right)$ и борная кислота $\left(\mathrm{H}_{3} \mathrm{BO}_{3}\right)$. Опробованы два способа синтеза: осаждение из раствора и твердофразный синтез. Показано, что оптимальным вариантом кристаллизации $\mathrm{LiB}_{3} \mathrm{O}_{5}$ и $\mathrm{Li}_{2} \mathrm{~B}_{4} \mathrm{O}_{7}$ является непосредственное спекание механически измельченной стехиометрической смеси исходных веществ. Специфика кристаллизации боратов лития исследовалась в температурном интервале от 500 до $850^{\circ} \mathrm{C}$. Пробоотбор проводился через каждые $50^{\circ} \mathrm{C}$. Установлены частные фазовые портреты, то есть совокупность характеристик процесса в зависимости от уровня организации частиц вещества, субсолидусной кристаллизации из исходной смеси реагентов три- и тетрабората лития на фразовом, локальном и структурном уровнях. На фразовом уровне в смеси со стехиометрией трибората лития максимум преобразования кристаллических фраз наблюдается в области 500-600 ${ }^{\circ} \mathrm{C}$, для тетрабората лития температурный максимум находится в диапазоне $600-700{ }^{\circ} \mathrm{C}$. Последовательность фразовых преобразований при этом остается практически неизменной и происходит по схеме: исходные вещества - промежуточные метастабильные фразы - конечные бораты. Локальный уровень фразовых портретов характеризует взаимодействие координационных полиэдров, образующих кристаллическую решетку исследованных фаз: твердофазный синтез кристаллического $\mathrm{LiB}_{3} \mathrm{O}_{5}$ из исходных $\mathrm{Li}_{2} \mathrm{CO}_{3}$ и $\mathrm{H}_{3} \mathrm{BO}_{3}$ происходит за счет перехода $\left(\mathrm{BO}_{3}\right)^{3-} \rightarrow\left(\mathrm{B}_{3} \mathrm{O}_{7}\right)^{5-}$, а при получении $\mathrm{Li}_{2} \mathrm{~B}_{4} \mathrm{O}_{7}$ реализуется схема $\left(\mathrm{BO}_{3}\right)^{3-} \rightarrow\left(\mathrm{B}_{4} \mathrm{O}_{9}\right)^{6-}$. Нa уровне кристаллической структуры таким переходам соответствуют преобразования моноклинной решетки первичных фраз $\mathrm{Li}_{2} \mathrm{CO}_{3}$ и $\mathrm{H}_{3} \mathrm{BO}_{3}$ в ромбическую и тетрагональную структуру $\mathrm{LiB}_{3} \mathrm{O}_{5} \mathrm{u}$ $\mathrm{Li}_{2} \mathrm{~B}_{4} \mathrm{O}_{7}$ cоответственно. Промежуточной ступенью такого преобразования являются тригональный цепочечный метаборат $\mathrm{LiBO}_{2}$ и метастабильный $\mathrm{Li}_{2} \mathrm{~B}_{8} \mathrm{O}_{13}$.

Ключевые слова: синтез боратов, триборат лития, тетраборат лития, система $\mathrm{Li}_{2} \mathrm{O}-\mathrm{B}_{2} \mathrm{O}_{3}$, твердофазный синтез, фразовый портрет кристаллизации

Благодарности: Приведенные в работе данные получены на оборудовании ЦКП «Изотопногеохимических исследований» Института геохимии им. А.П. Виноградова СО РАН. Исследование проведено в рамках выполнения государственного задания по проекту IX.25.3.2. «Кристаллические и аморфные функциональные материалы с прогнозируемыми свойствами» (0350-2019-0002).

Информация о статье: Дата поступления август 2019 е.; дата принятия к печати 25 февраля 2020 е.; дата онлайн-размещения 31 марта 2020 г.

Для цитировани.я: Мамонтова С.Г., Дергин А.А., Непомнящих А.И., Канева Е.В. Особенности синтеза три- и тетрабората лития в субсолидусной области. Известия вузов. Прикладная химия и биотехнология. 2020. T. 10. N 1. С. 6-13. https://doi.org/10.21285/2227-2925-2020-10-1-6-13

\section{INTRODUCTION}

The $\mathrm{Li}_{2} \mathrm{O}-\mathrm{B}_{2} \mathrm{O}_{3}$ system plays an important role in glass manufacturing technology. The compounds formed in this system are characterised by a number of unique properties [1, 2]. In particular, lithium triborate $\left(\mathrm{LiB}_{3} \mathrm{O}_{5}\right)$ is a highly in-demand material used to create effective nonlinear media for converting laser radiation. Lithium tetraborate $\left(\mathrm{Li}_{2} \mathrm{~B}_{4} \mathrm{O}_{7}\right)$ presents a promising material for nonlinear detectors $[3,4]$. It should be noted that the vast majority of experimental studies of this system were initially devoted to the production of single crystals [5]. However, the emphasis later shifted to the study of lithium-borate glasses. Recent publications confirm that lithium borate-based glasses doped with rare-earth elements - including praseodymium [6], samarium [7, 8], dysprosium [9], europium [10], as well as their combinations [11] are among the most advanced thermoluminescent and scintillation materials. In connection with the manifestation of these properties, the topology and structure of lithium borates are of particular interest [12].

One the one hand, an important advantage of glassy matrices consists in the relative simplicity of the technology for their derviation. On the other hand, the synthesis of these materials is hampered due to the complex nature of the phase transformations accompanying their crystallisation. Taking all the above into consideration, a need arises for the construction of an accurate phase diagram of the $\mathrm{Li}_{2} \mathrm{O}-\mathrm{B}_{2} \mathrm{O}_{3}$ system and ternary systems constituting it. Such studies, which were begun in the 1950s [13, 14], are still ongoing [15-17]. However, a full thermodynamic description of the $\mathrm{Li}_{2} \mathrm{O}-\mathrm{B}_{2} \mathrm{O}_{3}$ system is yet to be completed, including in the crystallisation region for the otherwise welldescribed compounds lithium triborate and lithium tetraborate.

As is known, the basic stage of thermodynamic research involves a consideration of the nature of phase formation during the interaction of system components. A mixture of lithium carbonate and boric acid is acknowledged to be the highestyielding precursor for the synthesis of lithium borates in the $\mathrm{Li}_{2} \mathrm{O}-\mathrm{B}_{2} \mathrm{O}_{3}$ system [18]. Therefore, the present work was mainly focused on the synthesis of the most monophasic material of a given stoi- 
chiometry for obtaining glass with the required properties.

\section{EXPERIMENTAL PART}

$\mathrm{Li}_{2} \mathrm{CO}_{3}$ and $\mathrm{H}_{3} \mathrm{BO}_{3}$ of extra pure grade were used following complete desiccation at $100{ }^{\circ} \mathrm{C}$. Phase interactions were studied in the temperature range of $300-850{ }^{\circ} \mathrm{C}$.

Two methods for preparing the initial mixture for the synthesis of lithium borates were tested: precipitation of components from solution and solid-phase sintering of the mechanically agitated dry reagents. The criteria for determining these methods included their rapidity and the absence of impurities in the system.

For the precipitation of target compounds from the liquid phase, a saturated solution of boric acid in distilled water was prepared. Then it was heated to $60{ }^{\circ} \mathrm{C}$ and a calculated stoichiometric amount of lithium carbonate was added according to the reactions:

$$
\begin{aligned}
& \mathrm{Li}_{2} \mathrm{CO}_{3}+6 \mathrm{H}_{3} \mathrm{BO}_{3} \rightarrow 2 \mathrm{LiB}_{3} \mathrm{O}_{5}+\mathrm{CO}_{2}+9 \mathrm{H}_{2} \mathrm{O} \\
& \mathrm{Li}_{2} \mathrm{CO}_{3}+4 \mathrm{H}_{3} \mathrm{BO}_{3} \rightarrow \mathrm{Li}_{2} \mathrm{~B}_{4} \mathrm{O}_{7}+\mathrm{CO}_{2}+6 \mathrm{H}_{2} \mathrm{O}
\end{aligned}
$$

The completion of the reaction was monitored by the cessation of gas emission. The solution was evaporated followed by the drying of precipitate at $100^{\circ} \mathrm{C}$ and a sampling for analysis. For subsequent solid-phase sintering, the dried precipitate was powdered in a porcelain mortar and transferred to alundum crucibles.

The preparation of the mixture for solid-phase synthesis and sintering included:

a) grinding of the starting reagents;

b) taking sample weights corresponding to stoichiometry of the target phases;

c) mixing to obtain visual uniformity.

The resulting batch was also placed in crucibles.

The solid-phase synthesis of the target phases was carried out in air according to the technique for obtaining lithium triborate presented in [18]. In order to remove water, the mixture was heated from room temperature to $300^{\circ} \mathrm{C}$ at a rate of 4 ${ }^{\circ} \mathrm{C} / \mathrm{min}$ and left for $1 \mathrm{~h}$. Then, after removing the crucibles from the furnace, the mixtures were remixed and heated at the same rate in the range of $400-850^{\circ} \mathrm{C}$ (for $\mathrm{LiB}_{3} \mathrm{O}_{5}$, the maximum temperature was $800^{\circ} \mathrm{C}$ ). For every $50^{\circ} \mathrm{C}$ step, curing and sampling from each crucible was carried out for an hour followed by further heating.

X-ray diffraction analysis of the samples was carried out using a Bruker D8 Advance diffractometer (CuK $K_{\alpha}$-radiation, scintillation detector, Goebel mirror, $\Delta 2 \Theta=0.02$ step mode). Data processing was performed using the DIFFRACplus software package. XRD reflections were identified using the PDF-2 powder diffractometry database (ICDD, 2007) and EVA software (Bruker, 2007).

\section{RESULTS AND DISCUSSION}

The main objective of this study consisted in obtaining monophasic lithium tri- and tetraborate for subsequent manufacture of glass products.

In the field of $\mathrm{LiB}_{3} \mathrm{O}_{5}$ and $\mathrm{Li}_{2} \mathrm{~B}_{4} \mathrm{O}_{7}$, the studies of several authors were combined for the $\mathrm{Li}_{2} \mathrm{O}-$ $\mathrm{B}_{2} \mathrm{O}_{3}$ phase diagram (Fig. 1). The basis formed by the well-known study [14] was supplemented by data presented in [15-17] and reduced to a single expression of component concentrations in weight percent. The melting points of lithium borates were taken into account according to the results given in [16] and interpreted by the authors on the basis of the Raman spectra. According to these data, $\mathrm{LiB}_{3} \mathrm{O}_{5}$ and $\mathrm{Li}_{2} \mathrm{~B}_{4} \mathrm{O}_{7}$ melts at 857 and $927^{\circ} \mathrm{C}$, respectively. Therefore, the coefficient of solid-phase synthesis $\left(K=T_{\text {synth }} / T_{\text {melt }}\right)$ in present experiments was: $\mathrm{K}\left(\mathrm{LiB}_{3} \mathrm{O}_{5}\right)=0.93, \mathrm{~K}\left(\mathrm{Li}_{2} \mathrm{~B}_{4} \mathrm{O}_{7}\right)=0.92$.

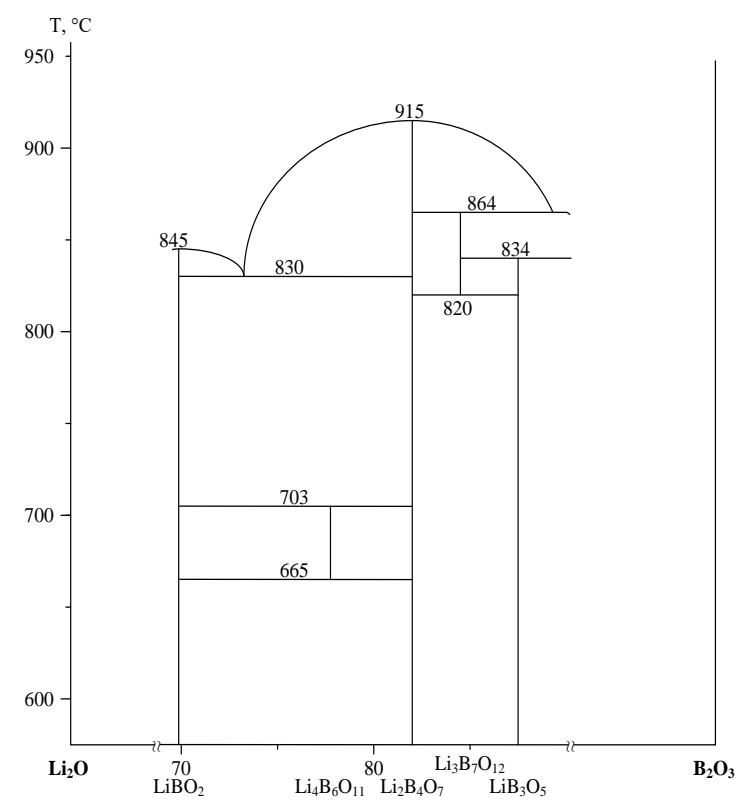

Fig. 1. State diagram of the system $\mathrm{Li}_{2} \mathrm{O}-\mathrm{B}_{2} \mathrm{O}_{3}$ in the region of existence of $\mathrm{LiB}_{3} \mathrm{O}_{5}$ and $\mathrm{Li}_{2} \mathrm{~B}_{4} \mathrm{O}_{7}$ (according to [13-17])

Puc. 1. Диаграмма состояния системы $\mathrm{Li}_{2} \mathrm{O}-\mathrm{B}_{2} \mathrm{O}_{3}$ в области существования $\mathrm{LiB}_{3} \mathrm{O}_{5}$ u $\mathrm{Li}_{2} \mathrm{~B}_{4} \mathrm{O}_{7}$ (по данным [13-17])

X-ray diffraction analysis demonstrated the sequence and nature of phase transformations to be almost identical during phase crystallisation from stoichiometric mixtures of both lithium triand tetraborate. In addition, no differences in the phase formation pattern were detected during solid-phase synthesis using both mechanical agitation and chemical precipitation sample preparation methods. Nevertheless, the crystallisation of each compound under consideration is characterised by its own specifics. Let us consider these in more detail.

As a result of the chemical interaction of lithium carbonate with boric acid in an aqueous solu- 


\section{S. G. Mamontova, A. A. Dergin, A. I. Nepomnyashchikh, et al. Aspects of lithium tri- and... \\ С.Г. Мамонтова, А.А. Дергин, А.И. Непомнящих и др. Особенности синтеза три- и...}

tion, mixtures of lithium borates with different component ratios were formed. According to the X-ray diffraction data, crystalline lithium tri- and tetraborate were present in the evaporated precipitate. However, further extraction and purification of the target compounds from the solution was a rather laborious process. In order to purify the phases by means their further crystallisation, the obtained precipitates were subjected to further solid-phase sintering.

A characteristic difference in the formation of lithium triborate compared with the tetraborate consists in the lower temperature region of the phase transformations resulting in target phase. The diffraction patterns of the stages in the solid-state synthesis illustrate the temperature ranges of the main phase transformations in the system. Thus, the maximum conversion of crystalline phases was recorded in the ranges of $500-600$ and $600-700^{\circ} \mathrm{C}$ in a lithium triborate (Fig. 2) and tetraborate (Fig. 3) mixtures, respectively. In both cases, a significant increase is observed in the amount of the target phase against the background of a sharp decrease in the proportion of the amorphous phase and intermediate compounds. It is noteworthy that $\mathrm{Li}_{2} \mathrm{~B}_{4} \mathrm{O}_{7}$, presented in a small quantity even in the final product of synthesis, comprised an essential component for the synthesis of lithium triborate.

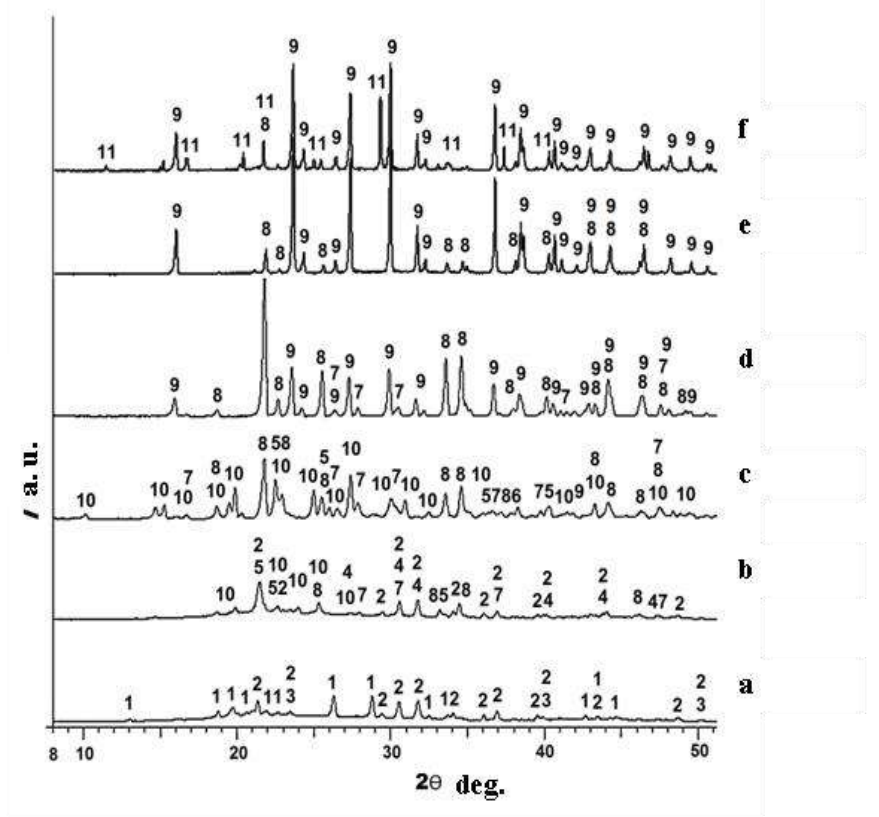

Fig. 2. Diffraction patterns of the main stages of lithium triborate solid-phase synthesis at the temperature, ${ }^{\circ} \mathrm{C}$ : 300 (a), 500 (b), 600 (c), 700 (d), 750 (e), 800 (f); 1 - Li(OH) ${ }_{2} \mathrm{~B}_{5} \mathrm{O}_{7}$;

$2-\mathrm{Li}_{2} \mathrm{CO}_{3} ; 3-\mathrm{H}_{3} \mathrm{BO}_{3} ; 4-\mathrm{LiBO}_{2} \cdot 8 \mathrm{H}_{2} \mathrm{O} ; 5-\mathrm{LiB}(\mathrm{OH})_{4}$;

$6-\mathrm{B}_{2} \mathrm{O} ; 7-\mathrm{LiBO}_{2} ; 8-\mathrm{Li}_{2} \mathrm{~B}_{4} \mathrm{O}_{7}, 9-\mathrm{LiB}_{3} \mathrm{O}_{5}, 10-\mathrm{Li}_{2} \mathrm{~B}_{8} \mathrm{O}_{13}$; $11-\mathrm{Li}_{3} \mathrm{~B}_{7} \mathrm{O}_{12}$

Puc. 2. Дифрактограммы основных этапов твердофразного синтеза трибората лития при температуре ${ }^{\circ} \mathrm{C}: 300$ (a), 500 (b), 600 (c), 700 (d), 750 (e), 800 (f); 1 - $\mathrm{Li}(\mathrm{OH})_{2} \mathrm{~B}_{5} \mathrm{O}_{7} ; 2-\mathrm{Li}_{2} \mathrm{CO}_{3} ; 3-\mathrm{H}_{3} \mathrm{BO}_{3}$; $4-\mathrm{LiBO}_{2} \cdot 8 \mathrm{H}_{2} \mathrm{O} ; 5-\mathrm{LiB}(\mathrm{OH})_{4} ; 6-\mathrm{B}_{2} \mathrm{O} ; 7-\mathrm{LiBO}_{2}$; $8-\mathrm{Li}_{2} \mathrm{~B}_{4} \mathrm{O}_{7}, 9-L i B_{3} \mathrm{O}_{5}, 10-\mathrm{Li}_{2} \mathrm{~B}_{8} \mathrm{O}_{13} ; 11-\mathrm{Li}_{3} \mathrm{~B}_{7} \mathrm{O}_{12}$

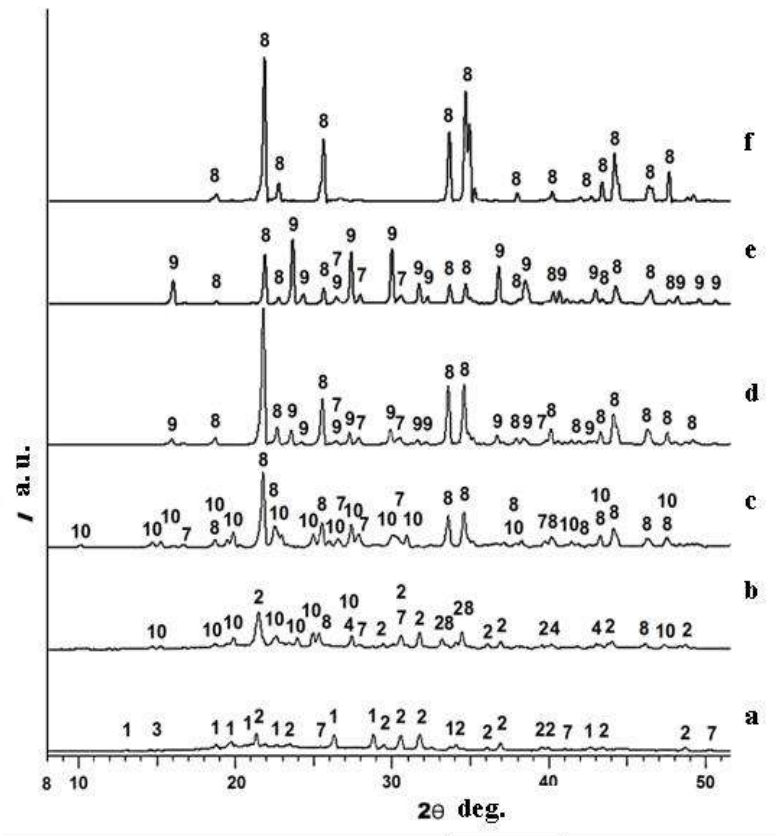

Fig. 3. Diffraction patterns of the main stages of lithium tetraborate solid-phase synthesis at the temperature, ${ }^{\circ} \mathrm{C}: 300$ (a), 500 (b), 600 (c), $700(d), 750(e), 800(f)$;

1 - $\mathrm{Li}(\mathrm{OH})_{2} \mathrm{~B}_{5} \mathrm{O}_{7} ; 2-\mathrm{Li}_{2} \mathrm{CO}_{3} ; 3-\mathrm{H}_{3} \mathrm{BO}_{3}$

$4-\mathrm{LiBO}_{2} \cdot 8 \mathrm{H}_{2} \mathrm{O} ; 5-\mathrm{LiB}(\mathrm{OH})_{4} ; 6-\mathrm{B}_{2} \mathrm{O}$;

$7-\mathrm{LiBO}_{2} ; 8-\mathrm{Li}_{2} \mathrm{~B}_{4} \mathrm{O}_{7} ; 9-\mathrm{LiB}_{3} \mathrm{O}_{5} ; 10-\mathrm{Li}_{2} \mathrm{~B}_{8} \mathrm{O}_{13}$ $11-\mathrm{Li}_{3} \mathrm{~B}_{7} \mathrm{O}_{12}$

Puc. 3. Дифрактограммы основных этапов твердофразного синтеза тетрабората лития при температуре, ${ }^{\circ} \mathrm{C}: 300$ (a), 500 (b), 600 (c), 700 (d), 750 (e), 800 (f);

$1-\mathrm{Li}(\mathrm{OH})_{2} \mathrm{~B}_{5} \mathrm{O}_{7} ; 2-\mathrm{Li}_{2} \mathrm{CO}_{3} ; 3-\mathrm{H}_{3} \mathrm{BO}_{3}$;

$4-\mathrm{LiBO}_{2} \cdot 8 \mathrm{H}_{2} \mathrm{O} ; 5-\mathrm{LiB}(\mathrm{OH})_{4} ; 6-\mathrm{B}_{2} \mathrm{O}$;

$7-\mathrm{LiBO}_{2} ; 8-\mathrm{Li}_{2} \mathrm{~B}_{4} \mathrm{O}_{7} ; 9-\mathrm{LiB}_{3} \mathrm{O}_{5} ; 10-\mathrm{Li}_{2} \mathrm{~B}_{8} \mathrm{O}_{13}$ $11-\mathrm{Li}_{3} \mathrm{~B}_{7} \mathrm{O}_{12}$

Using the terminology for ranking the organisation levels of the particles making up the substance [19] of the studied part of the $\mathrm{Li}_{2} \mathrm{O}-\mathrm{B}_{2} \mathrm{O}_{3}$ system, the local phase portrait of the crystal structure transformation is as follows. The monoclinic lattice of the primary phases, represented by the remains of hydrated $\mathrm{Li}(\mathrm{OH})_{2} \mathrm{~B}_{5} \mathrm{O}_{7}$ and the initial $\mathrm{Li}_{2} \mathrm{CO}_{3}$, is converted into the rhombic and tetragonal lithium tri- and tetraborate structures, respectively. The intermediate stage of this transformation appears as both the $\mathrm{Li}_{2} \mathrm{~B}_{8} \mathrm{O}_{13}$, detected in a minimal amount only at a temperature of $650^{\circ} \mathrm{C}$ in the form of a monoclinic and rhombic variation, and the trigonal chain metaborate $\mathrm{LiBO}_{2}$ accompanying the crystallisation in terms of $\mathrm{LiB}_{3} \mathrm{O}_{5}$ and $\mathrm{Li}_{2} \mathrm{~B}_{4} \mathrm{O}_{7}$ in the high-temperature range of $700-750{ }^{\circ} \mathrm{C}$.

Taking into account the detailed description of the lithium borate structures provided in [20] and assuming the crystallographic polyhedron to be the unit of transformation at the structural level, the local phase portrait of the subsolidus crystallisation of lithium triborate and tetraborate was established to consist in the $\left(\mathrm{BO}_{3}\right)^{3-} \rightarrow\left(\mathrm{B}_{3} \mathrm{O}_{7}\right)^{5-}$ and $\left(\mathrm{BO}_{3}\right)^{3-} \rightarrow\left(\mathrm{B}_{4} \mathrm{O}_{9}\right)^{6-}$ 


\section{S. G. Mamontova, A. A. Dergin, A. I. Nepomnyashchikh, et al. Aspects of lithium tri- and... \\ С.Г. Мамонтова, А.А. Дергин, А.И. Непомнящих и др. Особенности синтеза три- и...}

transitions, respectively. On this basis, the presence of lithium metaborate can be assumed to be an intermediate step facilitating the transition from the monoclinic island structure of the starting materials (lithium carbonate and boric acid) to the more complex lithium tri- and tetraborate structures, respectively.

\section{CONCLUSIONS}

1. The mechanical grinding of $\mathrm{Li}_{2} \mathrm{CO}_{3}$ and $\mathrm{H}_{3} \mathrm{BO}_{3}$ precursor stoichiometric mixtures followed by sintering was experimentally established to represent an efficient method for the synthesis of lithium tri- and tetraborate. The precipitation of batch components from solution provided no significant improvement in the results of the experiment.

2 . The synthesis of crystalline lithium borates in the subsolidus region is characterised by a set of individual phase portraits. At the phase level, a higher temperature region of the maximum in phase transformation is observed for $\mathrm{Li}_{2} \mathrm{~B}_{4} \mathrm{O}_{7}$ compared to $\mathrm{LiB}_{3} \mathrm{O}_{5}\left(600-700{ }^{\circ} \mathrm{C}\right.$ and $500-600{ }^{\circ} \mathrm{C}$, respectively) with a practically unchanged se-quence of phase transformations according to the scheme: starting materials $\rightarrow$ intermediate metastable phases $\rightarrow$ final borates. At the local level, the interaction of coordination polyhedra of the starting $\mathrm{Li}_{2} \mathrm{CO}_{3}$ with $\mathrm{H}_{3} \mathrm{BO}_{3}$ is followed by the formation of either $\mathrm{LiB}_{3} \mathrm{O}_{5}$ or $\mathrm{Li}_{2} \mathrm{~B}_{4} \mathrm{O}_{7}$ due to the $\left(\mathrm{BO}_{3}\right)^{3-} \rightarrow\left(\mathrm{B}_{3} \mathrm{O}_{7}\right)^{5-}$ and $\left(\mathrm{BO}_{3}\right)^{3-} \rightarrow\left(\mathrm{B}_{4} \mathrm{O}_{9}\right)^{6-}$ transitions, respectively. At the structural level, the occurring transformations are characterised by the transition of the monoclinic lattice of the $\mathrm{Li}_{2} \mathrm{CO}_{3}$ and $\mathrm{H}_{3} \mathrm{BO}_{3}$ primary phases into the $\mathrm{LiB}_{3} \mathrm{O}_{5}$ and $\mathrm{Li}_{2} \mathrm{~B}_{4} \mathrm{O}_{7}$ rhombic and tetragonal structures, respectively. In this case, the stage of lithium metaborate formation appears to be a prior condition for the crystallisation of more complex structures.

\section{REFERENCES}

1. Anjaiah J, Laxmikanth $C$, Veeraiah $N$, Kristaiah $P$. Luminescence properties of $\mathrm{Pr}^{3+}$ doped $\mathrm{Li}_{2} \mathrm{O}-\mathrm{MO}-$ $\mathrm{B}_{2} \mathrm{O}_{3}$ glasses. Journal of Luminescence. 2015; 161:147-153. https://doi.org/10.1016/j.jumin.2015.01.007

2. Pawar PP, Munishwar SR, Gedam RS. Intense white light luminescent $\mathrm{Dy}^{3+}$ doped lithium borate glasses for W-LED: A correlation between physical, thermal, structural and optical properties. Solid State Sciences. 2017;64:41-50. https://doi.org/ 10.1016/j.solidstatesciences.2016.12.009

3. Laorodphan N, Kidkhunthod P, Khajonrit J, Montreeuppathum A, Chanlek N, Pinitsoontorn S, et al. Effect of $\mathrm{B}_{2} \mathrm{O}_{3}$ content on structure-function of vanadium-lithium-borate glasses probed by synchrotron-based XAS and vibrating sample magnetrometry technique. Journal of Non-Crystalline Solids. 2018; 497:56-62. https://doi.org/10.1016/j.jnoncrysol. 2018.04 .045

4. Saidu $A$, Wagiran $H$, Saeed MA, Obayes HK, Bala A, Usman F. Thermoluminescence response of rare earth activated zinc lithium borate glass. $R a-$ diation Physics and Chemistry. 2018;144:413-418. https://doi.org/10.1016/j.radphyschem.2017.10.004

5. Neumair SC, Vanicek S, Wurst K, Huppertz H, Kaindl R, Többens DM. High-pressure synthesis and crystal structure of the lithium borate $\mathrm{HP}-\mathrm{LiB}_{3} \mathrm{O}_{5}$. Journal of Solid State Chemistry. 2011; Vol. 184(9):2490-2497. https://doi.org/10. 1016/j.jssc.2011.07.011

6. Sanyal B, Goswami M, Shobha S, Prakasan V, Chawla SP, Krishnan M, et al. Synthesis and characterization of $\mathrm{Dy}^{3+}$ doped lithium borate glass for thermoluminescence dosimetry. Journal of Non-Crystalline Solids. 2017;475:184-189. https:// doi.org/10.1016/j.jnoncrysol.2017.09.016

7. Ramteke DD, Ganvira VY, Munishwar SR, Gedam RS. Concentration Effect of $\mathrm{Sm}^{3+}$ lons on Structural and Luminescence Properties of Lithium Borate Glasses. Physics Procedia. 2015;76:25-30. https://doi.org/10.1016/j.phpro.2015.10.005

8. Kindrat II, Padlyak BV, Drzewiecki A. Luminescence properties of the Sm-doped borate glasses. Journal of Luminescence. 2015;166:264-275. https://doi.org/10.1016/j.jlumin.2015.05.051

9. Mhareb MHA, Hashim S, Ghoshal SK, Alajerami YSM, Bqoor MJ, Hamdan Al, et al. Effect of $\mathrm{Dy}_{2} \mathrm{O}_{3}$ impurities on the physical, optical and thermoluminescence properties of lithium borate glass. Journal of Luminescence. 2016;177:366-372. https:// doi.org/10.1016/j.jlumin.2016.05.002

10. Danilyuk PS, Volovich PN, Rizak VM, Puga PP, Gomonai Al, Krasilinets VN. X-ray luminescence and spectroscopic characteristics of $\mathrm{Er}^{3+}$ ions in a glassy lithium tetraborate matrix. Optics and Spectroscopy. 2015;118(6):924-929. https://doi.org/10.1134/S00 $30400 \times 15060089$

11. Rimbach AC, Steudel F, Ahrens B, Schweizer $\mathrm{S}$. $\mathrm{Tb}^{3+}, \mathrm{Eu}^{3+}$, and $\mathrm{Dy}^{3+}$ doped lithium borate and lithium aluminoborate glass: Glass properties and photoluminescence quantum efficiency. Journal of Non-Crystalline Solids. 2018;499:380-386. https://doi.org/10.1016/j.jnoncrysol.2018.07.029

12. Bødker MS, Mauro JC, Youngman RE, Smedskjaer MM. Statistical mechanical modeling of borate glass structure and topology: prediction of superstructural units and glass transition temperature. Journal of physical chemistry b: biophysical chemistry, biomaterials, liquids, and soft matter. 2019;123(5):1206-1213. https://doi.org/10.1021/acs. jpcb.8b11926

13. Rollet AP, Bouaziz R. The binary system: lithium oxide-boric anhydride. Comptes Rendus de l'Academie des Sciences. 1955;240(25):2417-2419.

14. Sastry BSR, Hummel FA. Studies in Lithium Oxide Systems: I, $\mathrm{Li}_{2} \mathrm{O}-\mathrm{B}_{2} \mathrm{O}_{3}$. Journal of the American Ceramic Society. 1958;41(1):7-17. https://doi. org/10.1111/j.1151-2916.1958.tb13496.x

15. Meshalkin AB. Investigation of phase equi- 
libria and assessment of thermodynamic properties of melts in binary borate systems. Teplofizika aeromekhanika = Thermophysics and Aeromechanics. 2005;12(4):669-684. (In Russian)

16. Voron'ko YuK, Sobol' AA, Shukshin VE. Investigation of phase transformations in $\mathrm{LiB}_{3} \mathrm{O}_{5}$ and $\mathrm{Li}_{2} \mathrm{~B}_{4} \mathrm{O}_{7}$ during heating and melting by Raman spectroscopy. Neorganicheskie materialy = Inorganic Materials. 2013;49(9):991-997. (In Russian) https://doi.org/10.7868/S0002337X13090200

17. Bazarova ZhG, Nepomnyashchikh Al, Kozlov AA, Bogdan-Kurilo VD, Bazarov BG, Subanakov AK, et al. Phase Equilibria in the System $\mathrm{Li}_{2} \mathrm{O}-$ $\mathrm{MgO}-\mathrm{B}_{2} \mathrm{O}_{3}$. Russian Journal of Inorganic Chemistry. 2007;52(12):1971-1973. https://doi.org/10.1134/S00 $3602360712025 X$
18. Depci T, Özbayoğlu G, Yilmaz A. The effect of different starting materials on the synthesis of lithium triborate. Physicochemical Problems of Mineral Processing. 2007;41:101-105.

19. MikhailovMA, Mamontova SG, ZelentcovSZ, Demina TV, Belozerova OYu, Bogdanova LA. On the Coexistence of Chemically Similar Stable and Metastable Phases in the $\mathrm{BeO}-\mathrm{MgO}-\mathrm{Al}_{2} \mathrm{O}_{3}-$ $\mathrm{SiO}_{2}$ System. Journal of Surface Investigation: X-ray, Synchrotron and Neutron Techniques. 2018;12(4): 756-760. https://doi.org/10.1134/S1027451018040328

20. Gorelik VS, Vdovin AV, Moiseenko VN. Raman and hyper-rayleigh scattering in lithium tetraborate crystals. Journal of Russian Laser Research. 2003;24(6):553-605. https://doi.org/ 10.1023/B:JORR.0000004168.99752.0e

\section{БИБЛИОГРАФИЧЕСКИЙ СПИСОК}

1. Anjaiah J., Laxmikanth C., Veeraiah N., Kristaiah $\mathrm{P}$. Luminescence properties of $\mathrm{Pr}^{3+}$ doped $\mathrm{Li}_{2} \mathrm{O}-$ $\mathrm{MO}-\mathrm{B}_{2} \mathrm{O}_{3}$ glasses // Journal of Luminescence. 2015. Vol. 161. P. 147-153. https://doi.org/10.1016/j.jlumin. 2015.01.007

2. Pawar P.P., Munishwar S.R., Gedam R.S. Intense white light luminescent $\mathrm{Dy}^{3+}$ doped lithium borate glasses for W-LED: A correlation between physical, thermal, structural and optical properties // Solid State Sciences. 2017. Vol. 64. P. 41-50. https://doi.org/10.1016/j.solidstatesciences.2016.12.009

3. Laorodphan N., Kidkhunthod P., Khajonrit J., Montreeuppathum A., Chanlek N., Pinitsoontorn S., et al. Effect of $\mathrm{B}_{2} \mathrm{O}_{3}$ content on structure-function of vanadium-lithium-borate glasses probed by synchrotron-based XAS and vibrating sample magnetrometry technique // Journal of Non-Crystalline Solids. 2018. Vol. 497. P. 56-62. https://doi.org/10. 1016/j.jnoncrysol.2018.04.045

4. Saidu A., Wagiran H., Saeed M.A., Obayes H.K., Bala A., Usman F. Thermoluminescence response of rare earth activated zinc lithium borate glass // Radiation Physics and Chemistry. 2018. Vol. 144. P. 413-418. https://doi.org/10.1016/j.radphyschem. 2017.10.004

5. Neumair S.C., Vanicek S., Wurst K., Huppertz H., Kaindl R., Többens D.M. High-pressure synthesis and crystal structure of the lithium borate $\mathrm{HP}-\mathrm{LiB}_{3} \mathrm{O}_{5} / /$ Journal of Solid State Chemistry. 2011. Vol. 184. Issue 9. P. 2490-2497. https://doi. org/10.1016/j.jssc.2011.07.011

6. Sanyal B., Goswami M., Shobha S., Prakasan V., Chawla S.P., Krishnan M., et al. Synthesis and characterization of $\mathrm{Dy}^{3+}$ doped lithium borate glass for thermoluminescence dosimetry // Journal of Non-Crystalline Solids. 2017. Vol. 475. P. 184189. https://doi.org/10.1016/j.jnoncrysol.2017.09.016

7. Ramteke D.D., Ganvira V.Y., Munishwar S.R., Gedam R.S. Concentration Effect of Sm3+ Ions on Structural and Luminescence Properties of Lithium Borate Glasses // Physics Procedia. 2015. Vol. 76. P. 25-30. https://doi.org/10.1016/j.phpro.2015.10.005

8. Kindrat I.I., Padlyak B.V., Drzewiecki A. Lu- minescence properties of the Sm-doped borate glasses // Journal of Luminescence. 2015. Vol. 166. P. 264-275. https://doi.org/10.1016/j.jlumin.2015. 05.051

9. Mhareb M.H.A., Hashim S., Ghoshal S.K., Alajerami Y.S.M., Bqoor M.J., Hamdan A.I., et al. Effect of $\mathrm{Dy}_{2} \mathrm{O}_{3}$ impurities on the physical, optical and thermoluminescence properties of lithium borate glass // Journal of Luminescence. 2016. Vol. 177. P. 366-372. https://doi.org/10.1016/j.jumin.2016.05.002

10. Danilyuk P.S., Volovich P.N., Rizak V.M., Puga P.P., Gomonai A.I., Krasilinets V.N. X-ray luminescence and spectroscopic characteristics of $\mathrm{Er}^{3+}$ ions in a glassy lithium tetraborate matrix // Optics and Spectroscopy. 2015. Vol. 118. Issue 6. P. 924-929. https://doi.org/10.1134/S0030400X15060089

11. Rimbach A.C., Steudel F., Ahrens B., Schweizer $\mathrm{S}$. $\mathrm{Tb}^{3+}, \mathrm{Eu}^{3+}$, and $\mathrm{Dy}^{3+}$ doped lithium borate and lithium aluminoborate glass: Glass properties and photoluminescence quantum efficiency // Journal of Non-Crystalline Solids. 2018. Vol. 499. P. 380-386. https://doi.org/10.1016/j.jnoncrysol.2018. 07.029

12. Bødker M.S., Mauro J.C., Youngman R.E., Smedskjaer M.M. Statistical mechanical modeling of borate glass structure and topology: prediction of superstructural units and glass transition temperature // Journal of physical chemistry b: biophysical chemistry, biomaterials, liquids, and soft matter. 2019. Vol. 123. Issue 5. P. 1206-1213. https://doi.org/10.1021/acs.jpcb.8b11926

13. Rollet A.P., Bouaziz R. The binary system: lithium oxide-boric anhydride // Comptes Rendus de l'Académie des Sciences. 1955. Vol. 240. Issue 25. P. 2417-2419.

14. Sastry B.S.R., Hummel F.A. Studies in Lithium Oxide Systems: I, $\mathrm{Li}_{2} \mathrm{O}-\mathrm{B}_{2} \mathrm{O}_{3} / /$ Journal of the American Ceramic Society. 1958. Vol. 41. Issue 1. P. 7-17. https://doi.org/10.1111/j.11512916.1958. tb13496.x

15. Мешалкин А.Б. Исследование фразовых равновесий и оценка термодинамических свойств расплавов в бинарных боратных системах // Теп- 
лофизика и аэромеханика. 2005. Т 12. N 4. C. 669-684.

16. Воронько Ю.К., Соболь А.А., Шукшин В.Е. Исследование фазовых превращений в $\mathrm{LiB}_{3} \mathrm{O}_{5}$ и $\mathrm{Li}_{2} \mathrm{~B}_{4} \mathrm{O}_{7}$ при нагревании и плавлении методом спектроскопии комбинационного рассеяния света // Неорганические материалы. 2013. Т. 49. N 9. C. 991-997. https://doi.org/10.7868/S0002337X 13090200

17. Bazarova Zh.G., Nepomnyashchikh A.I., Kozlov A.A., Bogdan-Kurilo V.D., Bazarov B.G., Subanakov A.K., et al. Phase Equilibria in the System $\mathrm{Li}_{2} \mathrm{O}-\mathrm{MgO}-\mathrm{B}_{2} \mathrm{O}_{3} / /$ Russian Journal of Inorganic Chemistry. 2007. Vol. 52. Issue 12. P. 1971-1973. https://doi.org/10.1134/S003602360712025X

18. Depci T., Özbayoğlu G., Yilmaz A. The ef-

\section{Contribution}

Svetlana G. Mamontova, Alexander A. Dergin, Alexander I. Nepomnyashchikh, Ekaterina V. Kaneva carried out the experimental work, on the basis of the results summarized the material and wrote the manuscript. Svetlana G. Mamontova, Alexander A. Dergin, Alexander I. Nepomnyashchikh, Ekaterina V. Kaneva have equal author's rights and bear equal responsibility for plagiarism.

\section{Conflict interests}

The authors declare no conflict of interests regarding the publication of this article.

The final manuscript has been read and approved by all the co-authors.

\section{INFORMATION ABOUT THE AUTHORS}

Svetlana G. Mamontova,

Cand. Sci. (Geology and Mineralogy),

Researcher,

A.P. Vinogradov Institute of Geochemistry

SB RAS,

1a Favorsky St., Irkutsk 664033,

Russian Federation,

$\triangle$ e-mail: svelta@igc.irk.ru

\author{
Alexander A. Dergin, \\ Postgraduate Student, \\ A.P. Vinogradov Institute of Geochemistry \\ SB RAS, \\ 1a Favorsky St., Irkutsk 664033 , \\ Russian Federation, \\ e-mail: dergin@igc.irk.ru
}

Alexander I. Nepomnyashchikh, Dr. Sci. (Physics and Mathematics), Chief Researcher

A.P. Vinogradov Institute of Geochemistry

SB RAS,

1a Favorsky St., Irkutsk 664033,

Russian Federation,

e-mail: ainep@igc.irk.ru fect of different starting materials on the synthesis of lithium triborate // Physicochemical Problems of Mineral Processing. 2007. Vol. 41. P. 101-105.

19. Mikhailov M.A., MamontovaS.G., ZelentcovS.Z., Demina T.V., Belozerova O.Yu., Bogdanova L.A. On the Coexistence of Chemically Similar Stable and Metastable Phases in the $\mathrm{BeO}-\mathrm{MgO}-\mathrm{Al}_{2} \mathrm{O}_{3}-$ $\mathrm{SiO}_{2}$ System // Journal of Surface Investigation: X-ray, Synchrotron and Neutron Techniques. 2018. Vol. 12. Issue 4. P. 756-760. https://doi.org/10. 1134/S1027451018040328

20. Gorelik V.S., Vdovin A.V., Moiseenko V.N. Raman and hyper-rayleigh scattering in lithium tetraborate crystals // Journal of Russian Laser Research. 2003. Vol. 24. Number 6. P. 553-605. https://doi. org/10.1023/B:JORR.0000004168.99752.0e

\section{Критерии авторства}

Мамонтова С.Г., Дергин А.А., Непомнящих А.И., Канева Е.В. выполнили экспериментальную работу, на основании полученных результатов провели обощение и написали рукопись. Мамонтова С.Г., Дергин А.А., Непомнящих А.И., Канева Е.В. имеют на статью равные авторские права и несут равную ответственность за плагиат.

\section{Конфликт интересов}

Авторы заявляют об отсутствии конфрликта интересов.

Все авторы прочитали и одобрили окончательный вариант рукописи.

\section{СВЕДЕНИЯ ОБ АВТОРАХ}

Мамонтова Светлана Григорьевна, к.г.-м.н., научный сотрудник, Институт геохимии им. А.П. Виноградова $\mathrm{CO} \mathrm{PAH}$

664033 г. Иркутск, ул. Фаворского, 1а, Российская Федерация,

$\bowtie$ e-mail: svelta@igc.irk.ru

\section{Дергин Александр Александрович,} аспирант, Институт геохимии им. А.П. Виноградова CO PAH,

664033 г. Иркутск, ул. Фаворского, 1а, Российская Федерация, e-mail: dergin@igc.irk.ru

Непомнящих Александр Иосифович, д.ф.-М.Н., профрессор, главный научный сотрудник, Институт геохимии им. А.П. Виноградова $\mathrm{CO} \mathrm{PAH}$,

664033, г. Иркутск, ул. Фаворского, 1а, Российская Федерация, e-mail: ainep@igc.irk.ru 
Ekaterina V. Kaneva,

Cand. Sci. (Geology and Mineralogy),

Senior Researcher,

A.P. Vinogradov Institute of Geochemistry

SB RAS,

1a Favorsky St., Irkutsk 664033,

Russian Federation,

e-mail: kaneva@igc.irk.ru
Канева Екатерина Владимировна,

к.Г.-м.н., старший научный сотрудник, Институт геохимии им. А.П. Виноградова CO PAH,

664033, г. Иркутск, ул. Фаворского, 1а,

Российская Федерация,

e-mail: kaneva@igc.irk.ru 